\title{
Blood Profile of Growing Rabbits Fed Pro-Vitamin A Fortified Cassava Peel Meal Based Diets
}

\author{
Peter-Damian Chukwunomso JIWUBA ${ }^{1^{*}}$, Stanley Uzochukwu ILO ${ }^{2}$, Wisdom AMADURUONYE ${ }^{3}$, \\ Nonye Lilian AZODO ${ }^{1}$, Chinenye UZOMA ${ }^{1}$ \\ ${ }^{1}$ Department of Animal Production Technology, Federal College of Agriculture, P.M.B.7008, Ishiagu, Ebonyi State, Nigeria \\ ${ }^{2}$ Department of Animal Science, University of Nigeria, Nsukka, Enugu State, P.O.Box 3236 Nsukka Postal Code 410001, Nigeria \\ ${ }^{3}$ Department of Animal Breeding and Physiology, Michael Okpara University of Agriculture, Umudike, PMB 7267 Umuahia, Nigeria
}

\begin{abstract}
The effect of feeding pro-vitamin A cassava peel meal (PCPM) based diets to growing rabbits $(\mathrm{n}=48)$ for 61 days on their haematology and serum biochemical parameters was investigated. $\mathrm{T}_{1}, \mathrm{~T}_{2}, \mathrm{~T}_{3}$, and $\mathrm{T}_{4}$ diets were formulated with inclusion levels of $0,15,30$, and $45 \%$, respectively. In a completely randomized design, the rabbits were randomly allocated to four experimental groups of twelve animals each, with four rabbits constituting a replicate. On the last day of the study, blood samples were taken from each animal and analyzed for haematological and serum biochemical indices. The results of the proximate composition of experimental diets revealed that $\mathrm{T}_{2}, \mathrm{~T}_{3}$, and $\mathrm{T}_{4}$ had high $(\mathrm{p}<0.05)$ ash values. $\mathrm{T}_{1}$ diet had higher $(\mathrm{p}<0.05)$ metabolizable energy $(\mathrm{ME})$ in comparison with $\mathrm{T}_{3}$, and $\mathrm{T}_{4}$ diets. Red blood cells $(\mathrm{RBC})$ and white blood cells (WBC) were improved $(\mathrm{p}<0.05)$ significantly in 15,30 , and $45 \%$ PCPM inclusions. $\mathrm{T}_{3}$ and $\mathrm{T}_{4}$ had better $(\mathrm{p}<0.05)$ packed cell volume $(\mathrm{PCV})$ values, haemoglobin $(\mathrm{Hb})$, mean cell haemoglobin $(\mathrm{MCH})$, and mean cell haemoglobin concentration (MCHC) than $\mathrm{T}_{1}$ and $\mathrm{T}_{2}$. The treatment groups $\left(\mathrm{T}_{2}, \mathrm{~T}_{3}\right.$ and $\left.\mathrm{T}_{4}\right)$ had significantly higher $(\mathrm{p}<0.05)$ total protein, globulin, creatinine, total bilirubin, and aspartate amino transferase (AST). Cholesterol and urea levels were lowered significantly $(\mathrm{p}<0.05)$ in $\mathrm{T}_{3}$ and $\mathrm{T}_{4}$. All of the blood parameters were within the normal physiological range for clinically healthy rabbits, indicating that PCPM was beneficial to the rabbits' blood formation and health. $\mathrm{T}_{4}$ group had the best results and was recommended for enhanced rabbit production.
\end{abstract}

Key words: haematology, serum biochemistry, cassava peel, $\beta$ - carotene, rabbits, biofortification

\section{INTRODUCTION}

Rabbits are highly prolific livestock, play important roles in the provision of high quality animal protein to man and are extensively used as laboratory animals in the test for human diseases and drugs. Recently, rabbit production has gained popularity possibly not just due to its delicious high protein meat with low calories and fat contents and laboratory uses, but also because of its fast growth rate, short gestation interval, limited vital space, early maturity, ample nutritional spectrum, low capital intensity and no religious or social constraint against rabbit meat or rabbit production (Jiwuba et al., 2016a). Due to increasing popularity of rabbit production, it is therefore important to have a reliable set of normal haematological and biochemical reference values to aid in the diagnosis and prognosis of rabbit diseases in the tropics. Most of the normal reference values quoted in the literature were derived from rabbits reared under temperate environments. Hence, there is urgent need to develop

${ }^{*}$ Correspondence to:

E-mail:jiwubapc@gmail.comorjiwubapc@yahoo.com 
normal physiological haematological and serum biochemical reference values for rabbits reared under tropical conditions and fed tropical diets.

Cassava peel, a by-product of cassava root processing, is one of such alternative tropical feedstuff. The National Root Crops Research Institute (NRCRI), Umudike, in partnership with the International Institute of Tropical Research Institute (IITA), Ibadan, Nigeria, has recently introduced pro-vitamin A cassava variants (Jiwuba and Ezenwaka, 2016). The provitamin A cassava was produced through traditional plant breeding or bioengineering (Sayre et al., 2011). The provitamin A cassava root is high in vitamin A and carotenoids and has a light yellow colouration when processed into different forms. The yellow colour observed in these varieties of cassava has led to higher demand and possible higher income to the farmers. Carotenoids, which abound in the new cassava pro-vitamin A, have extensive applications as antioxidants in dietary supplements (Jiwuba et al., 2016b) as blood precursor of vitamin A. The peels abound as a result of the root's great demand for a variety of human and industrial purposes. Also based on the fact that Nigeria still stand first in the world in cassava production and cassava-based foods being a staple food in the diet of Nigerians, this may have attributed to the gross availability of the peel. The peels are usually considered to contribute meaningful environmental problems when poorly discarded as waste. Therefore, incorporation into diets of rabbits will help to reduce environmental hazards as a result of poor waste management in the country. The objective of this study was to assess the effects of the diets in which maize was replaced by provitamin A cassava peel meal on the serum biochemical and haematological indices of growing rabbits. We assume that inclusion of 15 to $45 \%$ of pro-vitamin A cassava peel meal will have a positive effect on blood profile of rabbit, due to its high pro-vitamin A content.

\section{MATERIAL AND METHODS}

The study was conducted at the rabbit section of Federal College of Agriculture, Ishiagu, Ivo Local Government Area, Ebonyi State. The College is located at latitude $5.56^{\circ} \mathrm{N}$ and longitude $7.31^{\circ} \mathrm{E}$ with an average annual rainfall of $1653 \mathrm{~mm}$, a normal temperature of $28.50{ }^{\circ} \mathrm{C}$, and a relative humidity of around $80 \%$.

National Root Crops Research Institute, Umudike, Abia State, Nigeria provided the fresh pro-vitamin A cassava peels (TMS01368, TMS011412, and TMS1371). The peels were then milled and used to formulate pro-vitamin A cassava peel containing diets after being dried to around $10 \%$ moisture content. Table 1 shows four diets $\mathrm{T}_{1}, \mathrm{~T}_{2}, \mathrm{~T}_{3}$, and $\mathrm{T}_{4}$ with inclusion levels of $0,15,30$, and $45 \%$, respectively.

The proximate compositions of experimental diets and test material (pro-vitamin A cassava peel meal) were determined using the method of AOAC (2000). Calculation of metabolizable energy (AAFCO, 1997) was employed:

$\mathrm{ME}=(3.5 \times$ protein $)+(8.5 \times$ fat $)+(3.5 \times$ nitrogen free extract) $\times 10$
Table 1: Composition of experimental diets

\begin{tabular}{|l|l|l|l|l|}
\hline & \multicolumn{4}{|c|}{ Dietary level (\%) } \\
\hline Ingredients & $\mathrm{T}_{1}$ & $\mathrm{~T}_{2}$ & $\mathrm{~T}_{3}$ & $\mathrm{~T}_{4}$ \\
\hline Maize & 45.00 & 30.00 & 15.00 & 0.00 \\
\hline $\begin{array}{l}\text { Pro-vitamin A cassava } \\
\text { peel meal }\end{array}$ & 0.00 & 15.00 & 30.00 & 45.00 \\
\hline Palm kernel meal & 17.00 & 17.00 & 17.00 & 17.00 \\
\hline Soya bean meal & 20.00 & 20.00 & 20.00 & 20.00 \\
\hline Wheat offal & 12.00 & 12.00 & 12.00 & 12.00 \\
\hline Fish meal & 2.00 & 2.00 & 2.00 & 2.00 \\
\hline Bone meal & 2.00 & 2.00 & 2.00 & 2.00 \\
\hline Limestone & 1.00 & 1.00 & 1.00 & 1.00 \\
\hline Methionine & 0.25 & 0.25 & 0.25 & 0.25 \\
\hline Lysine & 0.25 & 0.25 & 0.25 & 0.25 \\
\hline Salt & 0.25 & 0.25 & 0.25 & 0.25 \\
\hline Vitamin premix & 0.25 & 0.25 & 0.25 & 0.25 \\
\hline Total & 100 & 100 & 100 & 100 \\
\hline
\end{tabular}

At Michael Okpara University of Agriculture in Umudike, Abia State, Nigeria, 48 New Zealand white bucks were obtained. According to the approval and rules of the College's Animal Ethics Committee's research policy, the rabbits were stabilized for 21 days prior to the start of the study. Each animal was immunized against diseases that were common at the time. Prior to the experiment, they were dewormed with kepromec (Ivermectin) at a rate of $0.1 \mathrm{~mL}$ per rabbit subcutaneously and given an accaricide bath with Roys' Amitraz 20 at a rate of $1 \mathrm{~mL}$ per 2-litre water. Each rabbit was kept in a standard hutch that measured 120 by $150 \mathrm{~cm}$ and was lifted $120 \mathrm{~cm}$ from the ground. The rabbits were randomized into four experimental treatments. In a completely randomized design, the four treatments were assigned to the four experimental diets. For 61 days, each animal was fed a treatment diet. Fresh drinking water was provided on a regular basis.

Blood samples $(5 \mathrm{~mL})$ were collected individually from the forty-eight rabbits through the marginal ear vein using sterilized syringe on the last day of the study. For the assessment of haematological parameters, approximately $2.5 \mathrm{ml}$ of blood from each rabbit was collected into vials containing ethylene diamine tetra-acetic acid (EDTA) as an anticoagulant. Another set was taken and placed in heparinized tubes for serum biochemistry analysis. The samples were divided into two groups and for tested haematological and biochemical indices. Beckman Coulter Ac-T10 Laboratory haematology Blood Analyzer and Bayer DCA 2000+ HbA1c analyzer were used to test serum biochemistry and haematological parameters, respectively. Accordingly, mean cell haemoglobin $(\mathrm{MCH})$, mean cell volume (MCV), and mean cell haemoglobin concentrations (MCHC) were computed. 
The data was analyzed using the analysis of variance (ANOVA) method, as given by SAS (2008). The Duncan Multiple New Range Test was used to differentiate significant means.

\section{RESULTS AND DISCUSSION}

Table 2 shows the chemical composition of the experimental diets. The dry matter (DM) values in this study varied from 92.46 to $93.12 \%$ and were statistically similar ( $p>0.05$ ), and were comparable to the range of 90.95 to $93.29 \%$ provided by NRC (1997) for young rabbits. Though the incorporation of pro-vitamin A cassava peel meal had no effect $(p>0.05)$ on the crude protein (CP), the values observed in this study were comparable to $16 \%$ and $18 \% \mathrm{CP}$ requirements for growing rabbits stated by Omole and Onwudike (1982) and Abubakar et al. (2015), respectively. The CP range of $17.14-18.26 \%$ in the current study is higher than the $15.97-16.00 \%$ obtained by Njidda and Isidahomen (2009) and lower than the $24.03-24.25 \%$ recorded by Jiwuba et al. (2016c) for growing rabbits, but comparable to 18.03 $19.92 \%$ recommended by NRC (1997) for growing rabbits. Nonetheless, the CP values observed in this study followed a certain pattern, decreasing linearly with increasing levels of PCPM, suggesting that the slight but steady decrease in CP values might be attributable to the PCPM. The crude fibre (CF) range of $14.36-16.07 \%$ was similar ( $>>0.05$ ), and fell within the recommended range of $14-18 \%$ and $14-16 \%$ for young rabbits recommended by Mayer (1955) and Gidenne and Lebas (2002). In a previous study (Jiwuba, 2018), it was discovered that an adequate amount of dietary fibre lowers digestive difficulties, stimulates intestinal motility, and boosts rabbit growth. The study found a significant $(\mathrm{p}<0.05)$ increase in ash content as the PCPM level was increased, with $\mathrm{T} 4$ showing the highest numerical value and T1 having the least, implying that pro-vitamin A cassava peel meal is high in mineral. The treatment diets had no effect $(\mathrm{p}>0.05)$ on the ether extract (EE), however the reported $3.09-4.84 \%$ $\mathrm{EE}$ in this study is within the $2-5 \%$ crude fat requirement suggested for growing rabbits by Irlbeck (2001). The within recommended range for crude fat obtained in this study may be responsible for the glossy sleek hair of the experimental rabbits. The nitrogen free extract (NFE) was not significantly ( $p>0.05$ ) influenced by the treatments. NFE can be used to assess non-fibrous carbohydrates such as sugars and starches.
Agro waste, such as cassava peel, has been found to be high in fibre (Jiwuba and Jiwuba, 2020). In this study, T1 (control diet) had significantly $(\mathrm{p}<0.05)$ higher metabolizable energy levels than the other treatments. In this investigation, the observed range of $11.01-11.91 \mathrm{MJ} / \mathrm{kg}$ is in accordance with the recommended ranges of $10.00-11.72 \mathrm{MJ} / \mathrm{kg}$ and 10.46 - $11.72 \mathrm{MJ} / \mathrm{kg}$ for growing rabbits by Aduku and Olukosi (1990) and Pond et al. (1995), respectively.

Table 3 shows the chemical composition of pro-vitamin A cassava peel meal. According to chemical analyses, PCPM had $89.67 \%$ DM, 7.68\% CP, $17.69 \%$ CF, 9.46\% ash, $2.64 \%$ EE, $52.20 \% \mathrm{NFE}$, and $9.71 \mathrm{MJ} / \mathrm{kg}$ metabolizable energy. This study's DM value of $89.67 \%$ is comparable with 89.90 and $90.28 \%$ reported by Ajayi and Omotoso (2018), and Jiwuba et al. (2016b) for the same agricultural waste. The CP of 7.68\% for cassava peel is fairly high for cassava peel, however, it could be due to the biofortication of the cassava cultivars. However, the CP of $9.23 \%$ noted by Jiwuba et al. (2016b) for the peel of the same cassava cultivars is higher than the value reported in the current study. The differences can be explained by the plant's age and soil fertility. The CF value for PCPM in this study was $17.69 \%$, is higher than $12.93 \%$ reported by Jiwuba et al. (2016b) for the peel of the same cassava varieties. Hence, Jiwuba and Jiwuba (2020) noted that the crude protein and amino acids profile continues to decrease with age as crude fibre, hemicellulose, cellulose, and lignin increase with age. This study's high ash content of PCPM is more than $2.23 \%$ reported by Anaeto et al. (2013), but agreed well with 9.11\% and 9.74\% reported by Ajayi and Omotoso (2015) and Jiwuba et al. (2016b) for cassava peel meals, respectively. The high NFE and energy levels in this present are consistent with previous studies Buitrago et al. (2002) and Olafadehan (2011).

Table 3: Chemical composition of pro-vitamin A cassava peel meal

\begin{tabular}{|l|c|}
\hline Parameters (\%) & $\begin{array}{c}\text { Provitamin A } \\
\text { cassava peel meal }\end{array}$ \\
\hline Dry matter & 89.67 \\
\hline Crude protein & 7.68 \\
\hline Crude fibre & 17.69 \\
\hline Ash & 9.46 \\
\hline Ether extract & 2.64 \\
\hline Nitrogen free extract & 52.20 \\
\hline Metabolizable energy $(\mathrm{MJ} / \mathrm{kg})$ & 9.71 \\
\hline
\end{tabular}

$\mathrm{ME}=(3.5 \times$ protein $)+(8.5 \times$ fat $)+(3.5 \times$ nitrogen free extract $) \times 10$

Table 2: Chemical composition of experimental diets

\begin{tabular}{|l|c|c|c|c|c|c|}
\hline Parameters (\%) & $\mathrm{T}_{1}$ & $\mathrm{~T}_{2}$ & $\mathrm{~T}_{3}$ & $\mathrm{~T}_{4}$ & SEM & $\mathrm{p}$-value \\
\hline Dry matter & 92.46 & 92.91 & 92.78 & 93.12 & 1.51 & 0.857 \\
\hline Crude protein & 18.26 & 18.04 & 17.38 & 17.14 & 0.49 & 0.293 \\
\hline Crude fibre & 14.36 & 15.26 & 15.87 & 16.07 & 0.29 & 0.669 \\
\hline Ash & $3.71^{\mathrm{b}}$ & $5.11^{\mathrm{a}}$ & $6.09^{\mathrm{a}}$ & $6.25^{\mathrm{a}}$ & 0.10 & 0.027 \\
\hline Ether extract & 4.84 & 3.54 & 3.12 & 3.09 & 0.08 & 0.498 \\
\hline Nitrogen free extract & 50.29 & 50.96 & 50.32 & 50.57 & 1.37 & 0.411 \\
\hline Metabolizable energy $(\mathrm{MJ} / \mathrm{kg})$ & $11.91^{\mathrm{a}}$ & $11.36^{\mathrm{ab}}$ & $11.02^{\mathrm{b}}$ & $11.01^{\mathrm{b}}$ & 2.29 & 0.007 \\
\hline
\end{tabular}

a-b means within the same row with different superscripts are significantly different $(\mathrm{P}<0.05) ; \mathrm{T}_{1}, \mathrm{~T}_{2}, \mathrm{~T}_{3}, \mathrm{~T}_{4}-0,15,30,45 \%$ pro-vitamin $\mathrm{A}$ cassava peel meal, respectively; $\mathrm{ME}=(3.5 \times$ protein $)+(8.5 \times$ fat $)+(3.5 \times$ nitrogen free extract $) \times 10$ 
Table 4 shows the haematological indices of growing rabbits fed pro-vitamin A cassava peel meal. The packed cell volume (PCV) did not follow any particular pattern, but it was significantly $(\mathrm{p}<0.05)$ higher in $\mathrm{T}_{3}$ and $\mathrm{T}_{4}$ than in $\mathrm{T}_{1}$ and $\mathrm{T}_{2}$. The haemoglobin $(\mathrm{Hb})$, mean cell haemoglobin $(\mathrm{MCH})$, and mean cell haemoglobin concentration (MCHC) all followed the same pattern as $\mathrm{PCV}$, with $\mathrm{T}_{3}$ and $\mathrm{T}_{4}$ values higher $(\mathrm{p}<0.05)$ than $\mathrm{T}_{1}$ and $\mathrm{T}_{2} . \mathrm{T}_{1}$ had a lower $\mathrm{RBC}(\mathrm{p}<0.05)$, in comparison to treatment groups $\left(\mathrm{T}_{2}, \mathrm{~T}_{3}\right.$, and $\left.\mathrm{T}_{4}\right)$. The white blood cells (WBC) differed significantly $(\mathrm{p}<0.05)$, with $\mathrm{T}_{3}$ and $\mathrm{T}_{4}$ having significantly higher values $(\mathrm{p}<0.05)$ than $\mathrm{T}_{1}$ and $\mathrm{T}_{2}$. The PCV range reported in this study was $37.87-45.55 \%$, which was within the normal physiological ranges of $36-48 \%, 34-50 \%$, and $31-50 \%$ for apparently healthy rabbits recommended by Aiello and Mays (1998), Hrapkiewicz and Medina (2007), and Hem et al. (2001), respectively. The rabbits fed the $\mathrm{T}_{3}$ and $\mathrm{T}_{4}$ diets produced higher results, indicating a lack of anti-nutrients or a tolerable level of anti-nutrients, as well as increased blood supply. The $\mathrm{Hb}$ concentrations reported in this study for $\mathrm{T}_{1}$ and $\mathrm{T}_{4}$ were $9.89-15.06 \mathrm{~g} / \mathrm{l}$, respectively, and fell within Fudge's (1996) range of $9.4-17 \mathrm{~g} / \mathrm{dl}$ for apparently healthy rabbits. The within normal physiological range may indicate that the quality of the diets in terms of protein were not compromised and hence supported higher oxygen carrying capacity of the blood among the animals. However, the higher $\mathrm{Hb}$ levels for rabbits fed $\mathrm{T}_{3}$ and $\mathrm{T}_{4}$ in comparison to $\mathrm{T}_{1}$ and $\mathrm{T}_{2}$ may be attributed to increased absorptive capacity occasioned by vitamin $\mathrm{A}$, which is essential micronutrient in rabbit diets that enhances gene expression, development, growth and immune system. The RBC range of $4.55-7.11 \times$ $10^{12} / \mathrm{L}$ obtained in this investigation was within the ranges of $4.0-7.2 \times 10^{12} / \mathrm{L}$ and $4.5-8.5 \times 10^{12} / \mathrm{L}$ reported for clinically healthy rabbits by Hillyer and Quesenberry (1997) and Bellier et al. (2005). The diets promoted improved transportation of haemoglobin via the red blood cells of the animals, as evidenced by greater RBC values. In addition, Hackbath et al. (1983) linked better RBC values with high-quality dietary protein and disease-free animals. The high CP and dietary fibre of the diets and the rabbits' lack of health challenges demonstrated this during the experiment period. Higher RBC concentration, on the other hand, was linked by Jiwuba et al. (2020b) to better oxidation of digested feed and improved body functioning. The non-significant ( $p>0.05)$ influence of diets on mean cell volume reported in this study agrees with Jiwuba et al. (2020a) and Jiwuba et al. (2016a) earlier studies, but differs from Jiwuba et al. (2016c) and Onyekwere et al. (2018) findings for growing rabbits. The $\mathrm{MCH}$ value of 18.74 - $25.66 \mathrm{pg}$ found in this study complemented Jiwuba et al. (2016a) and Jiwuba et al. (2020b) for growing rabbits, which were 18.26 - $38.11 \mathrm{pg}$ and $19.21-23.49$ pg, respectively. A higher $\mathrm{MCH}$ content could indicate the lack of anemia and the bone marrow's ability to produce RBC with normal size and metabolic capacity. This also ruled out the possibility of anemia among the rabbits, even if the feeding was extended. The MCHC in this study $(28.65-33.65 \%)$ fell within the normal range of 27 - 37\% indicated by RAR (2009) for young rabbits. This also suggested that the animals were not anemic. The WBC levels in this study ranged from $6.46-12.33 \times$ $10^{9} / 1$ for $\mathrm{T}_{1}$ and $\mathrm{T}_{4}$, respectively, and were within the ranges of $5-13 \times 10^{9} / 1$ and $4.0-13.0 \times 10^{9} / 1$, suggested by Burke (1994) and Hem et al. (2001) respectively for healthy growing rabbits. This suggested that there was no microbial infection or parasite in the rabbit's blood, implying that including provitamin A cassava peel in the rabbit's diet had no negative impact on the animals' immunity or general health. This is in line with the findings of Moriguchi et al. (1996), who found that supplementing with beta-carotene increased the generation of lymphocytes, an indicator of immunological function and immune cell surveillance. However, the role of adequate dietary fibre in maintaining gut health, general health and general performance of the rabbits in this current study cannot be over emphasized. Earlier studies (Cheeke, 1994; Jenkins, 1999) have shown that diets with lower dietary fibre below the minimum requirements can result in reduced gastro-intestinal motility, prolonged retention of digesta within the caecum, decreased formation of caecotrophs and a higher incidence of enteritis and diarrhea, which affects the general health and performance of the animals.

Table 5 shows the serum biochemical parameter of growing rabbits fed pro-vitamin A cassava peel meal in their diets. In comparison to the control group, total protein was significantly superior $(\mathrm{p}<0.05)$ in the treatment groups. Albumin, glucose and amino transferase (ALT) levels did not differ significantly ( $p>0.05$ ) between treatments and did not follow a pattern with increasing or decreasing PCLM levels. The globulin level increased steadily $(\mathrm{p}<0.05)$ with increasing amount of PCLM in the meals, with $\mathrm{T}_{1}$ having the minimum value and $\mathrm{T}_{4}$ having the maximum. With increasing quantities of PCLM in the rabbits' diets. Serum urea values were significantly influenced $(\mathrm{p}<0.05)$ and declined linearly with $\mathrm{T}_{1}$ having the greatest value and $\mathrm{T}_{4}$ having the lowest value. Serum

Table 4: Haematological parameters of growing rabbits fed pro-vitamin A cassava peel meal in their diets

\begin{tabular}{|l|c|c|c|c|c|c|}
\hline Parameters & $\mathrm{T}_{1}$ & $\mathrm{~T}_{2}$ & $\mathrm{~T}_{3}$ & $\mathrm{~T}_{4}$ & SEM & $\mathrm{p}$-value \\
\hline Packed cell volume (\%) & $37.87^{\mathrm{b}}$ & $39.73^{\mathrm{b}}$ & $45.55^{\mathrm{a}}$ & $43.29^{\mathrm{a}}$ & 6.19 & 0.027 \\
\hline Haemoglobin $(\mathrm{g} / \mathrm{l})$ & $9.89^{\mathrm{b}}$ & $10.67^{\mathrm{b}}$ & $14.33^{\mathrm{a}}$ & $15.06^{\mathrm{a}}$ & 3.34 & 0.003 \\
\hline Red blood cells $\left(\times 10^{12} / \mathrm{L}\right)$ & $4.55^{\mathrm{b}}$ & $6.75^{\mathrm{a}}$ & $7.11^{\mathrm{a}}$ & $6.02^{\mathrm{a}}$ & 1.23 & 0.021 \\
\hline Mean cell volume (fl) & 65.98 & 66.85 & 67.99 & 66.87 & 11.83 & 0.764 \\
\hline Mean cell haemoglobin $(\mathrm{pg})$ & $18.74^{\mathrm{b}}$ & $18.92^{\mathrm{b}}$ & $25.66^{\mathrm{a}}$ & $22.78^{\mathrm{a}}$ & 4.62 & 0.023 \\
\hline Mean cell haemoglobin concentration $(\%)$ & $28.65^{\mathrm{b}}$ & $28.87^{\mathrm{b}}$ & $32.09^{\mathrm{a}}$ & $33.65^{\mathrm{a}}$ & 5.78 & 0.000 \\
\hline White blood cells $\left(\times 10^{9} / \mathrm{l}\right)$ & $6.46^{\mathrm{c}}$ & $8.57^{\mathrm{b}}$ & $11.11^{\mathrm{a}}$ & $12.33^{\mathrm{a}}$ & 1.68 & 0.007 \\
\hline
\end{tabular}

${ }^{a-c}$ means within the same row with different superscripts are significantly different $(\mathrm{P}<0.05) ;$ ); $\mathrm{T}_{1}, \mathrm{~T}_{2}, \mathrm{~T}_{3}, \mathrm{~T}_{4}-0,15,30,45 \%$ pro-vitamin $\mathrm{A}$ cassava peel meal, respectively 
Table 5: Blood biochemical parameter of growing rabbits fed diets containing pro-vitamin A cassava peal meal

\begin{tabular}{|l|c|c|c|c|c|c|}
\hline & \multicolumn{5}{|c|}{ Dietary levels } & \\
\hline Parameters & $\mathrm{T}_{1}$ & $\mathrm{~T}_{2}$ & $\mathrm{~T}_{3}$ & $\mathrm{~T}_{4}$ & SEM & p-value \\
\hline Total protein $(\mathrm{g} / \mathrm{l})$ & $60.45^{\mathrm{c}}$ & $63.87^{\mathrm{b}}$ & $67.99^{\mathrm{ab}}$ & $71.81^{\mathrm{a}}$ & 1.54 & 0.005 \\
\hline Albumin $(\mathrm{g} / \mathrm{l})$ & 40.69 & 40.22 & 39.88 & 38.67 & 0.34 & 0.284 \\
\hline Globulin $(\mathrm{g} / \mathrm{l})$ & $19.76^{\mathrm{d}}$ & $23.65^{\mathrm{c}}$ & $28.11^{\mathrm{b}}$ & $32.33^{\mathrm{a}}$ & 0.27 & 0.001 \\
\hline Urea $(\mathrm{mmol} / \mathrm{L})$ & $8.12^{\mathrm{a}}$ & $7.45^{\mathrm{a}}$ & $6.55^{\mathrm{ab}}$ & $4.91^{\mathrm{b}}$ & 0.05 & 0.009 \\
\hline Creatinine (mmol/l) & $80.55^{\mathrm{d}}$ & $101.76^{\mathrm{c}}$ & $147.77^{\mathrm{b}}$ & $178.09^{\mathrm{a}}$ & 2.99 & 0.000 \\
\hline Cholesterol $(\mathrm{mmol} / \mathrm{l})$ & $2.02^{\mathrm{a}}$ & $1.44^{\mathrm{b}}$ & $0.98^{\mathrm{c}}$ & $0.56^{\mathrm{c}}$ & 0.01 & 0.002 \\
\hline Total bilirubin $(\mu \mathrm{mol} / \mathrm{l})$ & $4.54^{\mathrm{c}}$ & $6.43^{\mathrm{b}}$ & $6.31^{\mathrm{b}}$ & $8.21^{\mathrm{a}}$ & 0.08 & 0.024 \\
\hline Glucose $(\mathrm{mmol} / \mathrm{l})$ & 4.76 & 4.86 & 4.71 & 4.80 & 0.13 & 0.165 \\
\hline AST (U/L) & $43.66^{\mathrm{d}}$ & $51.87^{\mathrm{c}}$ & $60.56^{\mathrm{b}}$ & $71.19^{\mathrm{a}}$ & 0.62 & 0.000 \\
\hline ALT (U/L) & 32.77 & 30.88 & 33.17 & 31.49 & 0.31 & 0.429 \\
\hline
\end{tabular}

${ }^{\text {a-d }}$ means within the same row with different superscripts are significantly different $(\mathrm{P}<0.05)$; AST - Aspartate aminotransferase; ALT - Alanin aminotransferase; $\mathrm{T}_{1}, \mathrm{~T}_{2}, \mathrm{~T}_{3}, \mathrm{~T}_{4}-0,15,30,45 \%$ pro-vitamin A cassava peel meal, respectively

creatinine values differed $(\mathrm{p}<0.05)$ significantly and increased linearly per additional levels of PCLM in the rabbits' diets, with $\mathrm{T}_{4}$ showing the highest value and $\mathrm{T}_{1}$ showing the least. Total bilirubin levels were significantly $(\mathrm{p}<0.05)$ affected, with $\mathrm{T}_{4}$ having the maximum value and $\mathrm{T}_{1}$ having the minimum. The rabbits' aspartate aminotransferase (AST) values were significantly influenced $(\mathrm{p}<0.05)$ and increased progressively per additional level of PCLM in the diets. The total protein levels in this study $(60.45-71.81 \mathrm{~g} / \mathrm{l})$ were within the normal physiological ranges of $54-75 \mathrm{~g} / \mathrm{l}, 50-75 \mathrm{~g} / \mathrm{l}$, and $53-75$ g/l, respectively, reported by Wolfensohn and Lloyd (1998), RAR (2009), and Suckow and Douglas (1997) for clinically healthy young rabbits. Considering that, protein synthesis is connected to the amount of dietary protein provided to the animal; this could signal that there is no muscle loss and that the rabbits survived without depleting their body reserves. This also revealed that rabbits on the treatment diets used dietary protein more efficiently than those in the control group, thus do, allowing for higher protein availability and utilization. The increased globulin values found in the treatment groups in this study indicate that the experimental animals have a higher level of immunity and resistance to diseases. This may have accentuated the ethno-veterinary qualities of vitamin A, as described by Lin et al. (2006), who stated that vitamin A is required for consolidation immunity through antibody formation, and that its deficiency would reduce immunological response and increase infection. Perhaps the values of 19.76 - $32.33 \mathrm{~g} / \mathrm{l}$ obtained here were within the usual physiological ranges of $15-33 \mathrm{~g} / \mathrm{l}$ and $19-$ $35 \mathrm{~g} / \mathrm{l}$ for clinically healthy rabbits reported by BRV (2008) and Carpenter (2005), respectively, indicating that the diets supported the animals' immunity. Blood urea concentrations of $4.91-8.12 \mathrm{mmol} / \mathrm{l}$ in this investigation were within the ranges of $4.6-10.7 \mathrm{mmol} / \mathrm{l}$ and $6.1-8.4 \mathrm{mmol} / \mathrm{l}$ reported by BRV (2008) and Wolfensohn and Lloyd (1998) for apparently healthy growing rabbits, respectively. The reduced blood urea level recorded in $\mathrm{T}_{4}$ indicates that the diet's protein quality was improved, and so a high blood urea level is linked to poor protein quality Eggum (1970) or increased tissue catabolism complemented with protein insufficiency. This was in conformity with the findings of Jiwuba et al. (2016b) who fed pro-vitamin A cassava peel containing diets to West
African Dwarf goats. Serum creatinine concentration of the rabbits followed a specific pattern, with the bucks receiving the treatment diets demonstrating greater values than those in the control group. The values obtained in this investigation $(80.55-178.09 \mathrm{mmol} / \mathrm{l})$ were within the normal physiological ranges of $44-230 \mathrm{mmol} / \mathrm{l}$ and $71-227 \mathrm{mmol} / \mathrm{l}$, respectively, for apparently growing rabbits, as reported by BRV (2008) and Kaneko et al. (1997). This indicated that the rabbits' kidneys were not failing and that they survived at no cost to their body reserves, as proven by the fact that they did not lose weight during the experiment. The serum cholesterol levels $(0.56-2.02 \mathrm{mmol} / \mathrm{l})$ found in this study are within the range of $0.3-2.6 \mathrm{mmol} / 1$ reported for seemingly healthy young rabbits by Suckow and Douglas (1997). The PCLM caused a considerable reduction in serum cholesterol levels, according to the current findings. Jiwuba et al. (2016b), on the other hand, found no significant effect of PCLM on cholesterol concentration in WAD goats fed pro-vitamin A cassava peel meal in their diets. The drop in serum cholesterol levels in rabbits on PCLM diets could imply a reduction in overall fat mobilization and that PCLM diets were able to lower cholesterol, hence supporting the reduction and deposition of cholesterol in the muscles and improving the production of lean meat The fact that serum cholesterol levels were within normal physiological ranges in this investigation ruled out the possibility of fat malabsorption, heart disease, or liver dysfunction in the rabbits. Total bilirubin concentrations of $4.54-8.21 \mathrm{mmol} / \mathrm{l}$ in this investigation were within the ranges of $3.4-8.6 \mathrm{mmol} / \mathrm{l}, 4.3-12.7 \mathrm{mmol} / \mathrm{l}$, and $3.4-12$ $\mathrm{mmol} / \mathrm{l}$ reported by Suckow and Douglas (1997), Wolfensohn and Lloyd (1998) and RAR (2009) for apparently healthy rabbits, respectively. Since total bilirubin is considered as an indicator of liver function, the fact that the diets were within normal clinical range in this study could signal that the diets were not harmful. The rabbits' AST concentrations followed a predictable pattern, with the rabbits on the treatment diets showing higher levels than the control group. The range of $43.66-71.19 \mathrm{U} / \mathrm{L}$ found in this investigation was within the usual physiological ranges of $20-120 \mathrm{U} / \mathrm{L}, 14-113 \mathrm{U} / \mathrm{L}$, and 10 - $98 \mathrm{U} / \mathrm{L}$ for apparently growing rabbits as reported by RAR (2009), Suckow and Douglas (1997), and BRV (1998), respectively. This indicated that the diets were of good quality. 


\section{CONCLUSION}

In conclusion, this study showed that pro-vitamin A cassava peel meal supported haematological and serum biochemical indices of growing rabbits and therefore could be added in the diets of young rabbits up to $45 \%$ without any detrimental effect on the health status and erythropoiesis of the rabbits.

\section{REFERENCES}

1. Abubakar, M., Ibrahim, U., Yusuf, A. U., Muhammad, A. S., \& Adamu, N. (2015). Growth performance, carcass and organ characteristics of growing rabbits fed graded levels of Moringa oleifera leaf meal in diets. Bayero Journal of Pure and Applied Sciences, 8(2), 7-9. DOI: http://dx.doi.org/10.4314/bajopas.v8i2.2

2. Aduku, A. O., \& Olukosi, J. O. (1990). Rabbit management in the tropics: production, processing. utilization, marketing economics, practice, research and future prospects. Abuja: Living Book Series.

3. Aiello, S. E., \& Mays, A. (1998). The Merck veterinary manual. Whitehouse Station, NJ: Merck and Co., Inc. 8, 2187-2197.

4. Ajayi, T. F., \& Omotoso, O. S. (2018). Potential of albizia lebbeck-cassava peel silage as dry season feed for West African Dwarf Sheep. Pertanika Journal of Tropical Agricultural Science, 41(3), 1151-1167.

5. Anaeto, M., Sawyerr, A. F., Alli, T. R., Tayo, G. O., Adeyeye, J. A., \& Olarinmoye, A. O. (2013). Cassava leaf silage and cassava peel as dry season feed for West African Dwarf Sheep. Global Journal of Science Frontier Research Agriculture and Veterinary Sciences, 13(2).

6. AOAC. (2000).Association of Official Analytical Chemists: Official Methods of Analysis. 6th Edition. Washington DC, USA.

7. Bellier, S., Da Silva, N. R., Aubin-Houzelstein, G., Elbaz, C., Vanderwinden, J. M., \& Panthier, J. J. (2015). Accelerated intestinal transit in inbred mice with an increased number of interstitial cells of Cajal. AJPGastrointestinal and Liver Physiology, 288(1), 151-158.

8. Biochemistry Reference Values - BRV, MediRabbit. Com. (2008). Retrieved from: http://www.medirabbit. com/EN/Hematology/blood_chemistry.htm

9. Buitrago, J. A., Ospina, B., Gil, J. L., \& Aparicio, H. (2002). Cassava root and leaf meals as the main ingredients in poultry feeding: some experiences in Columbia. In $\mathrm{H}$. H. Reinhardt (Ed.). Cassava research and development in Asia: Exploring new opportunities for an ancient crop (pp. 523-541). Proceedings of the $7^{\text {th }}$ regional workshop held in Bangkok, Thailand.

10. Burke, J. (1994). Clinical care and medicine of pet rabbit. In: Proceedings of the Michigan Veterinary Conference (pp. 49 -77).

11. Carpenter, J. W. (2005). Exotic animal formulary. St. Louis, MO: Elsevier Saunders.

12. Eggum, B. O. (1970). Blood urea-measurement as a technique for assessing protein quality. British Journal of Nutrition, 24, 985-988.

13. Fudge, A. M. (1999). Laboratory medicine: Avian and exotic pets. Philadelphia: WB Saunders.
14. Gidenne, T., \& Lebas, F. (2002). Role of dietary fibre in rabbit nutrition and in digestive troubles prevention. 2nd Rabbit Congress of the Americas, Habana City, Cuba, June 19-22.

15. Hackbath, H., Buron, V., \& Schimansley, G. (1983). Strain difference in inbred rats: Influence of strain and diet on haematological traits. Laboratory Animals, 17, 7-12.

16. Hem, A., Eide, D. M., Engh, E., \& Smith, A. (2001). Kompendium $i$ Forsøksdyrlore. Oslo: Norges Veterinarhogskole.

17. Hillyer, E. V., \& Quesenberry, K. E. (1997). Ferrets, rabbits and rodents-Clinical medicine and surgery. Philadelphia: WB Saunders.

18. Hrapkiewicz, K., \& Medina, L. (2007). Clinical laboratory animal medicine. Ames: Blackwell Publishing.

19. Irlbeck, N. A. (2001). How to feed the rabbit (Orytolagus cuniculus) gastro-intestinal tract. Journal of Animal Science, 79, 343-346.

20. Jiwuba, P. C., Ezenwaka, L. C., Ikwunze, K., \& Nsidinanya, N. O. (2016b). Blood profile of West African Dwarf goats fed provitamin A cassava peel-centrosema leaf meal based diets. Analele Stiintifice ale Universitatii "Alexandru Ioan Cuz", Sectiunea Genetica si Biologie Moleculara, 17(3), 127-134.

21. Jiwuba. P. C., \& Ezenwaka, L. C. (2016). Growth performance and apparent nutrient digestibility of West African dwarf goats fed $\beta$-carotene cassava peelcentrosema leaf meal based diets. Case Studies Journal, 5(8), 204-210.

22. Jiwuba, P. C., Ikwunze, K., Duada, E., \& Ugwu, D. O. (2016c). Haematological and serum biochemical indices of growing rabbits fed diets containing varying levels of Moringa oleifera leaf meal. British Biotechnology Journal, 15(2), 1-7.

23. Jiwuba. P. C., \& Jiwuba, L. C. (2020). Productive and physiological response of small ruminants fed Cassava (Manihot esculenta Crantz) and cassava by-products in their diets: A review. Zhivotnovadni Nauki, 57(2), 17-31.

24. Jiwuba, P. C., Onwujiariri, E. B., \& Azodo, N. L. (2020a). Effect of diets with iron tree (Prosopis africana) pulp on performance and blood characteristics of growing rabbits. Asian Journal of Animal Science, 14, 61-68.

25. Jiwuba, P. C. (2018). Effect of pawpaw (Carica papaya) leaf meal on productive parameters of growing rabbits. Agricultural Science and Technology, 10(2): 102-106.

26. Jiwuba, P. C., Ikpe, U. O., \& Azodo, N. L. (2020b). Potential of Gmelina leaf meal diets on the productive and physiological characteristics of growing rabbits. Agricultural Science and Technology, 12(1), 13-18.

27. Jiwuba, P. C., Ugwu, D. O., Kadurumba, O. E., \& Dauda, E. (2016a). Haematological and serum biochemical indices of weaner rabbits fed varying levels of dried Gmelina arborea leaf meal. International Blood Research and Reviews, 6(2), 1-8.

28. Kaneko, J. J., Harvey, J. W., \& Bruss, M. L. (1997). Clinical Biochemistry of Domestic Animals. San Diego: Academic Press.

29. Lin, H., Jiao, H. C., Buyse, J., \& Decuypere, E. (2006). Strategies for preventing heat stress in poultry. World Poultry Science Journal, 62, 71-86. 
30. Mayer, J. (1955). Nutrition of rabbits. Kenilworth: Merck and Co.

31. Moriguchi, S., Okishima, N., \& Sumida, S. (1996). Beta-carotene supplementation enhances lymphocyte proliferation with mitogens in human peripheral blood lymphocytes. Nutritional Research, 16, 211-218.

32. Njidda, A. A., \& Isidahomen, C. E. (2009). Haematology, blood chemistry and carcass characteristics of growing rabbits fed grasshopper meal as a substitute for fish meal. Pakistan Veterinary Journal, 30(1), 7-12.

33. NRC. (1997). Nutrient requirements of rabbits. National Research council. National Academy of Science press, Washington DC, USA.

34. Olafadehan, O. A. (2011). Haematological parameters, serum constituents and organ development of growing rabbits as affected by feeding of processed cassava peel. Animal Nutrition and Feed Technology, 11, 41-51.

35. Omole, T. A., \& Onwudike, O. C. (1982). Effect of palm oil on the use of cassava peel meal by rabbit. Topical Animal Production, 8, 27-32.

36. Onyekwere, M. U., Jiwuba, P.C., \&Egu, U.N.(2018). Effect of diets with raw garlic flour on growth performance and blood parameters in rabbits. Agricultural Science and Technology, 10(4), 302-307.

37. Pond, W. G., Church, D. C., \& Pond, K. R. (1995). Basic animal nutrition and feeding, $4^{\text {th }}$ Edition. New York: John Wiley and Sons Publication.

38. Research Animal Resource (RAR). (2009). Reference values for laboratory animals: Normal haemotological values. Minneapolis: RAR, University of Minnesota.

Retrieved from: http://www.ahe.umn.edu.rar.refvalues. html

39. SAS. (2008). Statistical Analytical Systems, 9.4 for Windows x64 Based Systems. SAS Institute Inc., Cary, NC 27513, USA.

40. Sayre, R., Beeching, J. R., \& Cahoon, E. B. (2011). The biocassava plus program: biofortification of cassava for sub-saharan Africa. Annual Review of Plant Biology, 62, 251-272.

41. Suckow, M. A., \& Douglas, F. A. (1997). The laboratory rabbit. Boca Raton: CRC Press.

42. Wolfensohn, S., \& Lloyd, M. (1998). Handbook of laboratory animal management and welfare. Oxford: Blackwell Science Ltd. 


\section{Krvna slika pitovnih kuncev, krmljenih z obroki na osnovi s provitaminom A obogatene lupine kasave}

\section{IZVLEČEK}

V raziskavi so preučevali vpliv 61 dni trajajočega krmljenja pitovnih kuncev z obroki, ki so vključeval s provitaminom A obogateno lupino kasave (pro-ALK), na hematološke in serumske biokemične parametre. Obroki T1, T2, T3 in T4 so bili oblikovani tako, da so vključevali $0,15,30$ in $45 \%$ pro-ALK. V popolnoma slučajni poskusni zasnovi so bili kunci naključno razporejeni $v$ štiri poskusne skupine po 12 živali, pri čemer so 4 kunci predstavljali ponovitev. Zadnji dan raziskave so vsaki živali odvzeli vzorce krvi, v katerih so analizirali hematološke in serumske biokemične kazalce. Rezultati okvirne sestave eksperimentalnih obrokov so pokazali, da so imele skupine $\mathrm{T} 2, \mathrm{~T} 3$ in $\mathrm{T} 4$ višje $(\mathrm{p}<0,05)$ vsebnosti pepela kot obrok $\mathrm{T} 1$, obrok $\mathrm{T} 1 \mathrm{pa}$ je imel višjo vsebnost $(\mathrm{p}<0,05)$ presnovne energije $\mathrm{v}$ primerjavi z obrokoma T3 in T4. Rdeče in bele krvne celice so se znatno povečale $(\mathrm{p}<0,05)$ pri 15,30 in $45 \%$ vključitvi pro-ALK. Obroka T3 in T4 sta imela večje vrednosti $(\mathrm{p}<0,05)$ za volumen celic, vsebnost hemoglobina, povprečni celični hemoglobin in povprečno koncentracijo celičnega hemoglobina kot obroka T1 in T2. Poskusne skupine (T2, T3 in T4) so imele značilno višje vrednosti $(\mathrm{p}<0,05)$ skupnih beljakovin, globulina, kreatinina, skupnega bilirubina in aspartat aminotransferaze. Ravni holesterola in sečnine so se znatno znižale $(\mathrm{p}<0,05)$ pri obrokih T3 in T4. Vsi v krvi analizirani parametri so bili v normalnem fiziološkem območju za klinično zdrave kunce, kar kaže, da je bil pro-ALK koristen za tvorbo krvi in zdravje kuncev. Najboljši rezultati so bili dobljeni pri obroku T4, zaradi česar je bil ta obrok priporočen za izboljšanje prireje kuncev.

Ključne besede: hematologija, serumska biokemija, lupina kasave, $\beta$-karoten, kunec, biofortifikacija 